\title{
Parents experiences of handling oral anticancer drugs at home: "It all falls on me..."
}

\author{
Ranaa Akkawi El Edelbi ${ }^{1}$, Staffan Eksborg${ }^{2}$, Ulrika Kreicbergs ${ }^{3}$, Malin Lövgren ${ }^{4}$, Klara \\ Wallen $^{5}$, Jennie Ekman ${ }^{5}$, and Synnöve Lindemalm ${ }^{5}$ \\ ${ }^{1}$ Women and Children's Health Astrid Lindgrens Childrens Hospital \\ ${ }^{2}$ Karolinska Institute Department of Women's and Children's Health \\ ${ }^{3}$ Health Care Sciences/Palliative Research Centre \\ ${ }^{4}$ Ersta Sköndal Bräcke University College \\ ${ }^{5}$ Affiliation not available
}

February 25, 2022

\begin{abstract}
Aim: The aim of this study was to describe the experiences of parents handling oral anticancer drugs in a home setting. Methods: Parents of children with cancer were recruited from a pediatric oncology ward in Sweden to participate in an interview. The interviews were transcribed verbatim and subjected to qualitative content analysis. Results: We found the following categories and subcategories: parents' views on the provided information - lack of, too little or contradictory information, and parents' preferences for information delivery; safety over time; correct drug dose; and drug administration. As time passed, most parents adapted to their child's illness, felt safer, and found it easier to take in and process any given information. Parents preferred information in different formats (written, movie clips and orally) and in their mother tongue. Many parents were aware of the importance of giving an accurate dose to their child and described the process of drug administration as overwhelming. Conclusions: Parents need to be provided with accurate, timely, nonconflicting and repeated information - in different forms and in their mother tongue - on how to handle oral anticancer drugs at home.
\end{abstract}

\section{Hosted file}

Article, 220402.docx available at https://authorea.com/users/462386/articles/557828-parentsexperiences-of-handling-oral-anticancer-drugs-at-home-it-all-falls-on-me

\section{Hosted file}

210703_Table_1.doc available at https://authorea.com/users/462386/articles/557828-parentsexperiences-of-handling-oral-anticancer-drugs-at-home-it-all-falls-on-me

\section{Hosted file}

Table_2-acta.doc available at https://authorea.com/users/462386/articles/557828-parentsexperiences-of-handling-oral-anticancer-drugs-at-home-it-all-falls-on-me 


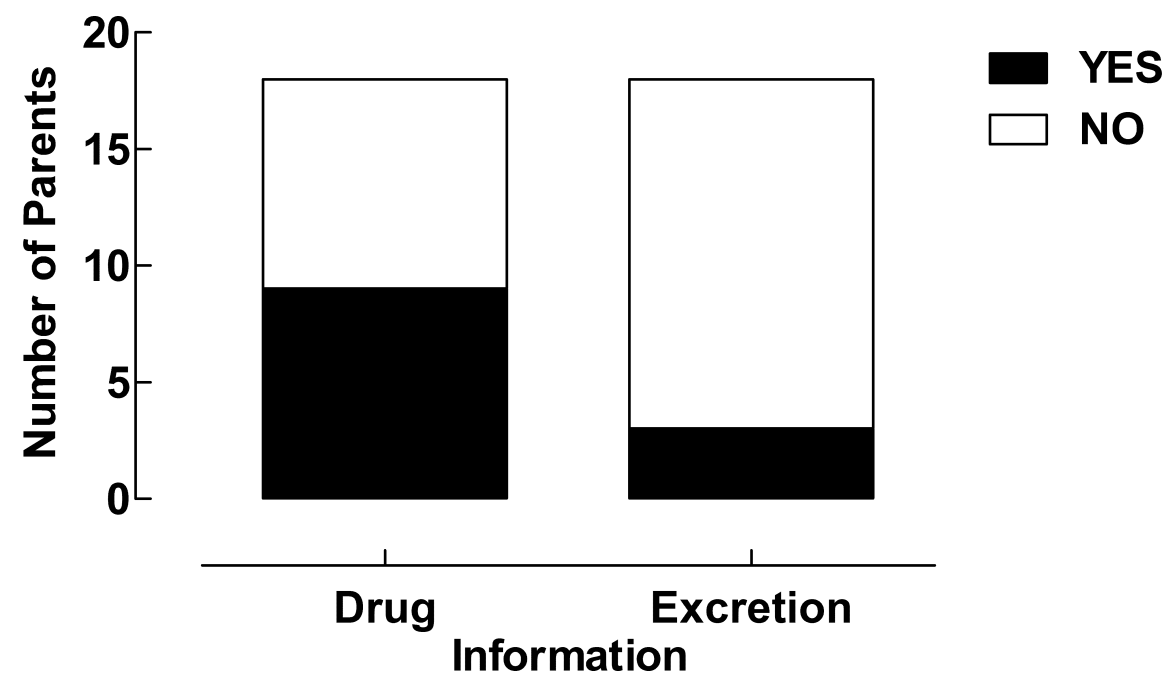

